\title{
Exogenous and endogenous nitrogen flow rates and level of protein hydrolysis in the human jejunum after $\left[{ }^{15} \mathrm{~N}\right] \mathrm{milk}$ and $\left[{ }^{15} \mathrm{~N}\right]$ yoghurt ingestion
}

\author{
BY CLAIRE GAUDICHON ${ }^{1}$, SYLVAIN MAHÉ ${ }^{1 *}$, NILS ROOS 2 , ROBERT \\ BENAMOUZIG ${ }^{3}$, CATHERINE LUENGO ${ }^{1}$, JEAN-FRANÇOIS HUNEAU ${ }^{1}$, \\ HINRICH SICK ${ }^{2}$, CHRISTINE BOULEY ${ }^{4}$, JACQUES RAUTUREAU ${ }^{3}$ \\ AND DANIEL TOME \\ ${ }^{1}$ Unité INRA de Nutrition Humaine et de Physiologie Intestinale, Faculté des Sciences \\ Pharmaceutiques et Biologiques, 4 avenue de l'Observatoire, 75006 Paris, France \\ ${ }^{2}$ Institut für Physiologie und Biochemie der Ernährung, Bundesanstalt für Milchforschung, \\ PO Box 6069, D-2300 Kiel 14, Germany \\ ${ }^{3}$ Service de Gastroentérologie, Hôpital Avicenne, 125 route de Stalingrad, \\ 93009 Bobigny Cédex, France \\ ${ }^{4}$ Groupe Danone, Branche Produits Frais, 15 avenue Galilée, 92350 Le-Plessis-Robinson, France
}

(Received 17 October 1994 - Accepted 6 January 1995)

\begin{abstract}
Milk and yoghurt proteins were ${ }^{15} \mathrm{~N}$-labelled in order to measure the flow rate of exogenous $\mathrm{N}$ during digestion in the human intestine. After fasting overnight, sixteen healthy volunteers, each with a nasojejunal tube, ingested either $\left[{ }^{15} \mathrm{~N}\right] \mathrm{milk}(n)$ ) or $\left[{ }^{15} \mathrm{~N}\right] \mathrm{yoghurt}(n$ 9). Jejunal samples were collected every $20 \mathrm{~min}$ for $4 \mathrm{~h}$. A significant stimulation of endogenous $\mathrm{N}$ secretion was observed during the $20-60 \mathrm{~min}$ period after yoghurt ingestion and the $20-40 \mathrm{~min}$ period after milk ingestion. The endogenous $\mathrm{N}$ flows over a 4 h period did not differ between the groups (44.3 (SEM 6.5) mmol for milk and 63.5 (SEM 5.9) mmol for yoghurt). The flow rates of exogenous $N$ indicated a delayed gastric emptying of the yoghurt $N$ compared with $\mathbf{N}$ from milk. The jejunal non-protein $\mathbf{N}$ (NPN) flow rate increased significantly after milk and yoghurt ingestion due to an increase in the exogenous NPN flow rate. The NPN fraction of exogenous $N$ ranged between 40 and $80 \%$. The net gastro-jejunal absorption of exogenous $N$ did not differ significantly between milk (56.7 (SEM 8.5) \%) and yoghurt (50.9 (SEM 7)\%). The high level of exogenous $\mathbf{N}$ hydrolysis is in accordance with the good digestibility of milk products. Fermentation modifies only the gastric emptying rate of $\mathbf{N}$ and does not affect the level of diet hydrolysis, the endogenous $\mathbf{N}$ stimulation or the digestibility rate.
\end{abstract}

Milk proteins: ${ }^{15} \mathrm{~N}$ : Digestion: Human: Jejunum

A great difficulty in the study of intestinal protein digestion in humans arises from the fact that after ingestion, dietary proteins are mixed with endogenous proteins secreted in the lumen, i.e. gastric, bilio-pancreatic and intestinal secretions. In addition, contrary to fasting conditions where endogenous proteins are continuously secreted into the lumen at a constant level (Gaudichon et al. 1994a), the ingestion of a meal stimulates salivary, gastric and bilio-pancreatic secretions (Alpers, 1987) to a level which depends on the amount and on the nature of the meal and particularly its dietary protein content (Lurie et al. 1973; Girard-Globa et al. 1980; Simon et al. 1983). Different methods have been developed to differentiate between exogenous and endogenous $N$ fractions in the intestinal chyme including the use of stable isotopes as markers of the alimentary compounds. Labelling the

* For reprints. 
proteins of milk with ${ }^{15} \mathrm{~N}$ constitutes an accurate method of differentiating precisely between endogenous and exogenous fractions in intestinal effluents. This method has also proved to be accurate in evaluating the kinetics of protein digestion and absorption as well as the secretory $\mathrm{N}$ response to a meal in both humans (Mahé et al. 1994c) and animals (Gaudichon et al. 1994b).

In a previous study we compared the $\mathrm{N}$ flow rates in the jejunum and the ileum in humans after milk and yoghurt ingestion (Mahé et al. 1994b). A significant increase in the $\mathrm{N}$ flow rate was observed in the jejunum with both meals. This increase was delayed with yoghurt compared with milk in the jejunum, whereas no difference was noticed at the ileal level. The jejunal effect could have been due partly to a delayed gastric emptying of yoghurt but could also have originated from the difference in endogenous $\mathrm{N}$ secretion. However, it was not possible to differentiate between endogenous and exogenous $\mathbf{N}$. The aim of the present study was to determine in humans (1) the endogenous $\mathrm{N}$ secretion in the jejunum after milk and yoghurt ingestion and (2) the level of hydrolysis in both endogenous and exogenous $\mathbf{N}$ fractions in the jejunum. For these purposes, human volunteers, each equipped with a naso-jejunal tube, received per os ${ }^{15} \mathrm{~N}$-labelled milk or yoghurt, jejunal effluents being collected for $4 \mathrm{~h}$.

\section{MATERIALS AND METHODS}

Diets

Fresh milk was ${ }^{15} \mathrm{~N}$-labelled by infusing $50 \mathrm{~g} / \mathrm{d}\left({ }^{15} \mathrm{NH}_{4}\right)_{2} \mathrm{SO}_{4}$ (10 atom \% isotope enrichment, Euriso-top, Saint Aubin, France) via a permanent fistula into the rumen of a lactating cow for 1 week as previously described (Mahé et al. 1994a). The milk of day 6 was enriched at 0.5083 atom $\%$ and was divided into two parts. The first part was used by Danone (Le-Plessis-Robinson, France) to prepare yoghurt. The second part was stored at $-20^{\circ}$ until fed to the volunteers. Diet composition is shown in Table 1. PEG-4000 was added to each diet as a non-absorbable liquid-phase marker (final concentration, $40 \mathrm{~g} / \mathrm{l}$ ).

\section{Subjects}

Sixteen healthy volunteers (eight male and eight female) participated in this study. They were 23 to 40 years of age (mean 30 years) and weighed from 49 to $95 \mathrm{~kg}$ (mean $66 \mathrm{~kg}$ ). None of the subjects had taken any medication or suffered from gastrointestinal upset before the study. The protocol was previously approved by the Ethical Committee of the hospital. All subjects gave informed consent for their participation in the study.

\section{Collection of digesta}

The day before the experiment the volunteers swallowed a double intestinal tube that descended by normal peristalsis to the jejunum. One tube was used to perfuse a saline $(150 \mathrm{~mm}-\mathrm{NaCl}$ ) solution of phenol red (PSP, a non-absorbable marker), and one to aspirate jejunal contents $200 \mathrm{~mm}$ distal to the perfusion site as previously described (Mahé $e t$ al. $1994 \mathrm{~b}$ ). After an overnight fast the intestinal tube was positioned under radioscopic control. Once the intestinal perfusion site was located at the proximal jejunum the test started by perfusing PSP at a flow rate of $1 \mathrm{ml} / \mathrm{min}$. Before meal ingestion, jejunal effluents were collected through the tube by continuous suction for $20 \mathrm{~min}$. These $20 \mathrm{~min}$ samplings were considered to be the basal period. At $\mathrm{T}_{0}$, subjects ingested either $300 \mathrm{ml}{ }^{15} \mathrm{~N}$-labelled milk $(n 7)$ or $300 \mathrm{~g}^{15} \mathrm{~N}$-labelled yoghurt $(n 9)$. Jejunal effluents were then pooled in $20 \mathrm{~min}$ intervals over ice for $4 \mathrm{~h}$. At the end of the experiment the subjects swallowed a gastric tube. The gastric contents were completely aspirated and the stomach was washed with $200 \mathrm{ml} 150 \mathrm{~mm}-\mathrm{NaCl}$ solution. The effluents were treated with $0 \cdot 1 \mathrm{~mm}$-diisopropylfluoro- 
Table 1. Amounts $(g)$ of dry matter, protein, carbohydrate and lipid ingested by humans fed with $300 \mathrm{ml}$ milk or $300 \mathrm{~g}$ yoghurt

\begin{tabular}{|c|c|c|}
\hline & $\begin{array}{c}\text { Milk } \\
(300 \mathrm{ml})\end{array}$ & $\begin{array}{l}\text { Yoghurt } \\
(300 \mathrm{~g})\end{array}$ \\
\hline $\begin{array}{l}\text { Dry matter } \\
\text { Protein }(\mathrm{N} \times 6.25) \\
\text { Carbohydrate } \\
\text { Lipid }\end{array}$ & $\begin{array}{l}42 \cdot 6 \\
10 \cdot 2 \\
13 \cdot 5 \\
15 \cdot 0\end{array}$ & $\begin{array}{l}42 \cdot 6 \\
10.8 \\
12.6 \\
13.8\end{array}$ \\
\hline
\end{tabular}

phosphate (Sigma Chemical Co., La Verpillière, France), then frozen at $-20^{\circ}$ and lyophilized.

\section{Protein precipitation}

Precipitable N (PN) and soluble N (NPN) were measured after ethanol precipitation of the dry samples as previously described (Mahé et al. 1994c). Samples were precipitated with ethanol $(700 \mathrm{ml} / 1)$ and centrifuged at $2400 \mathrm{~g}$ for $20 \mathrm{~min}$ at $4^{\circ}$. The pellet was believed to consist of proteins (PN) and the supernatant fraction to contain peptides and free amino acids (NPN).

\section{Isotope ratio analysis}

Total $\mathrm{N}$ and ${ }^{15} \mathrm{~N}$ enrichment in the dry digesta as well as in the PN and NPN fractions were measured by isotope-ratio mass spectrometry (IRMS) as previously described (Mahé et al. $1994 c$ ). Briefly, a portion of the lyophilized sample was burned in the presence of $\mathrm{O}_{2}$ in an elemental analyser (CHN-O-rapid; Heraeus, Hanau, Germany) at $950^{\circ}$. The combustion unit was coupled with an isotope-ratio mass spectrometer (delta E; Finnigan MAT, $\mathrm{GmbH}$, Bremen, Germany). The isotope ${ }^{14} \mathrm{~N}:{ }^{15} \mathrm{~N}$ ratio of $\mathrm{N}_{2}$ was measured with reference to a secondary laboratory standard. The values were calculated in atom $\%$ relative to atmospheric $\mathrm{N}_{2}$.

\section{Calculations and statistical analysis}

The jejunal flow rate was calculated from PSP concentration in the effluents and the perfusion solution. The exogenous $\mathrm{N}$ was calculated as follows:

$$
\mathbf{N}_{\text {exo }}=\mathbf{N}_{\text {tot }} \times\left(\mathrm{AP}_{\mathrm{s}}-\mathbf{A P}_{\mathbf{0}}\right) /\left(\mathrm{AP}_{\mathrm{d}}-\mathrm{AP}_{\mathbf{0}}\right) \text {, }
$$

where $N_{\text {tot }}$ is the amount of total $N$ in the sample, $A_{s}$ and $A_{d}$ are the ${ }^{15} \mathrm{~N}$ enrichment of the sample and of the diet respectively and $\mathrm{AP}_{0}$ is the natural enrichment in the intestinal segment before ingestion of exogenous ${ }^{15} \mathrm{~N}$. The endogenous $\mathrm{N}$ in the digesta $\left(\mathrm{N}_{\text {end }}\right)$ was calculated from the difference $\mathrm{N}_{\text {end }}=\mathrm{N}_{\text {tot }}-\mathrm{N}_{\text {exo }}$. The results were expressed as means with their standard errors. For differences between groups an ANOVA was done using the general linear model procedure (GLM, SAS/STAT 6.03; SAS Institute Inc., Cary, NC, USA). Time effects within each group were tested for significance $(\boldsymbol{P}<0.05)$ using Tukey's studentized range test.

\section{RESULTS}

Protein, non-protein nitrogen and total nitrogen flow rates

The flow rate of total $\mathrm{N}$ was measured at the jejunal level after the ingestion of either milk or yoghurt (Fig. 1). Before meal ingestion the $\mathrm{N}$ flow rate in the jejunum was $4 \cdot 7$ (SEM 0.8) $\mathrm{mmol} / 20 \mathrm{~min}$ in the milk group (M; $n$ 7) and 3.9 (SEM 0.3) $\mathrm{mmol} / 20 \mathrm{~min}$ in the yoghurt group ( $\mathrm{Y} ; n$ 9). After milk ingestion the total $\mathrm{N}$ flow rate peaked at $20 \mathrm{~min}$ and 


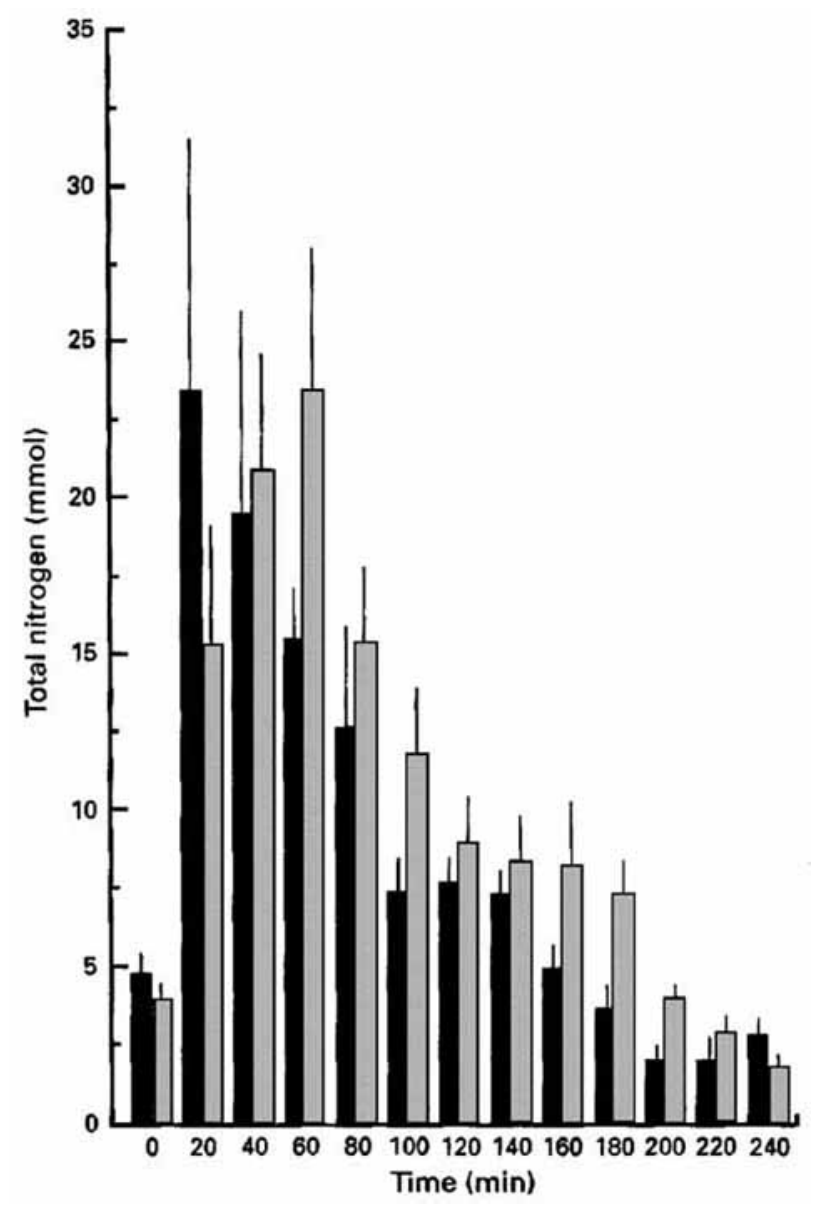

Fig. 1. Total nitrogen flow rates $(\mathrm{mmol} / 20 \mathrm{~min})$ in the jejunum of humans ingesting either $300 \mathrm{ml}\left[{ }^{15} \mathrm{~N}\right] \mathrm{milk}(\mathbf{D})$ or $\left.300 \mathrm{~g} \mathrm{[}{ }^{15} \mathrm{~N}\right]$ yoghurt (睁). Values are means for seven (milk) or nine (yoghurt) subjects, with their standard errors indicated by vertical bars. For details of products and procedures, see Table 1 and pp. $252-253$.

decreased progressively to return to a basal level after $160 \mathrm{~min}$. In subjects given yoghurt the total $\mathrm{N}$ flow rate was maximum at $60 \mathrm{~min}$ and returned to an initial level after $200 \mathrm{~min}$.

In order to characterize further the total $\mathrm{N}$ fraction in the jejunal effluents the PN and NPN fractions were separated by ethanol precipitation (Fig. 2). Before meal ingestion the PN fraction represented $45 \%$ of the basal $N$ secretion. In subjects fed with milk the PN fraction increased significantly compared with the basal level during the $20-40 \mathrm{~min}$ period $(P<0.05)$. After yoghurt ingestion a significant increase in total PN was observed for the 20-60 min period. The NPN fraction showed larger variations than PN. After milk ingestion the flow rate of NPN peaked at $20 \mathrm{~min}$ to a value of 14.4 (SEM 5.8$) \mathrm{mmol} / 20 \mathrm{~min}$ $(n 7)$ and returned to a basal level at $180 \mathrm{~min}$. The flow rate was significantly higher than the basal level until $80 \mathrm{~min}(P<0 \cdot 05)$. After yoghurt ingestion the NPN flow rate increased significantly for $100 \mathrm{~min}$ with a maximum of 16.5 (SEM 3.8) $\mathrm{mmol} / 20 \mathrm{~min}(n 9)$ at $60 \mathrm{~min}$.

\section{Exogenous and endogenous nitrogen flow rates}

The measurement of the ${ }^{15} \mathrm{~N}$ enrichment in the jejunal effluents allowed us to determine the contribution of exogenous sources to the PN, NPN and total $\mathbf{N}$ amounts (Fig. 3). The 

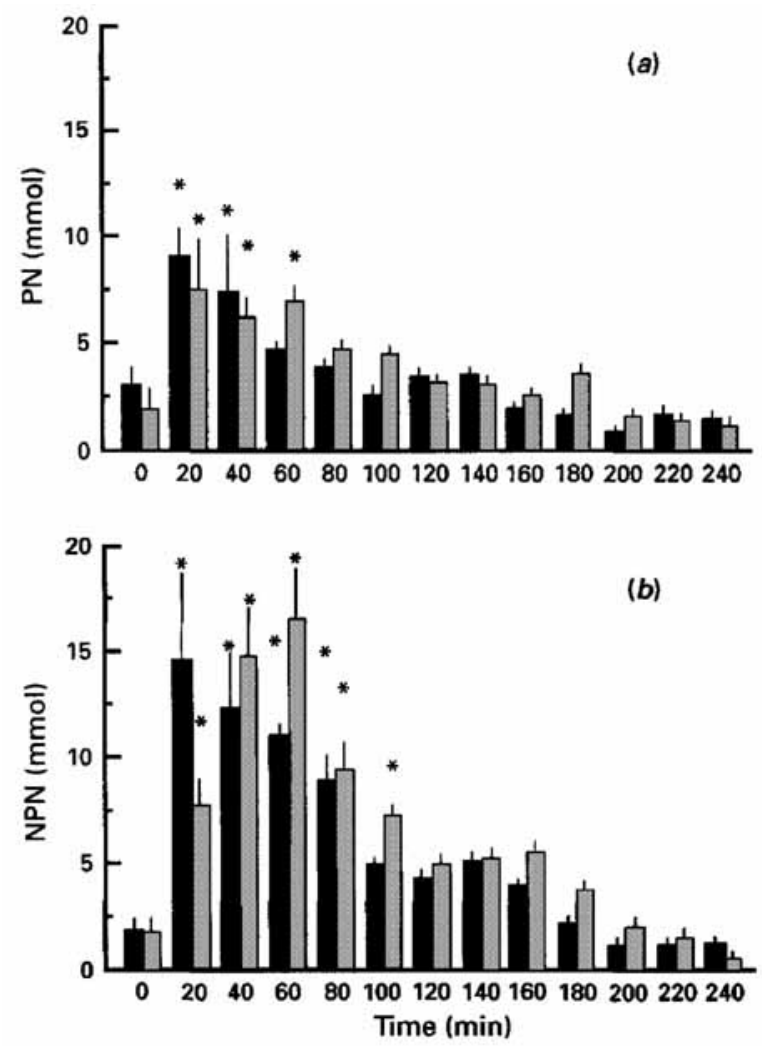

Fig. 2. Flow rates $(\mathrm{mmol} / 20 \mathrm{~min})$ of (a) protein nitrogen $(\mathrm{PN})$ and $(b)$ non-protein nitrogen (NPN) in the jejunum

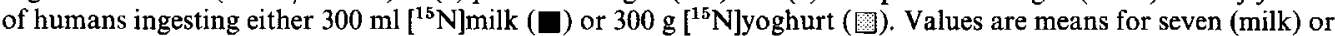
nine (yoghurt) subjects, with their standard errors indicated by vertical bars. * Mean value was significantly different from the basal value, $P<0.05$ (Tukey's studentized range test). For details of products and procedures, see Table 1 and pp. 252-253.

kinetics of the exogenous $\mathrm{N}$ flow rate were similar to those of the total $\mathrm{N}$ with a maximum at $20 \mathrm{~min}$ for subjects given milk and $60 \mathrm{~min}$ for those given yoghurt. After milk ingestion the proportion of NPN increased from $70 \%$ at $20 \mathrm{~min}$ to $78 \%$ at $100 \mathrm{~min}$ and then decreased to $40 \%$ at $240 \mathrm{~min}$. In the jejunum of humans ingesting yoghurt the NPN fraction peaked at 60 min and represented $64 \%$ of the exogenous $\mathrm{N}$ at this time and then decreased to $37 \%$ at $240 \mathrm{~min}$. The jejunal flow rates of the PN, NPN and total endogenous $\mathrm{N}$ are shown in Fig. 4. The total endogenous $\mathrm{N}$ flow rate was similar in both groups, with a significant increase $(P<0.05)$ compared with the basal level for $40 \mathrm{~min}$ for subjects given milk and for 60 min for subjects given yoghurt. The proportion of NPN was maximal at $67 \%$ of the total endogenous $\mathrm{N}$ at $60 \mathrm{~min}$ after milk ingestion and at $40 \mathrm{~min}$ after yoghurt ingestion.

\section{Endogenous nitrogen secretion and exogenous nitrogen absorption}

The sum of the different fractions of $\mathrm{N}$ recovered at the jejunal level during the $240 \mathrm{~min}$ following meal ingestion indicated that approximately $59 \%$ of the endogenous $\mathrm{N}$ and $69 \%$ of the exogenous $\mathrm{N}$ were in the form of NPN without any significant difference between subjects given milk and those given yoghurt (Table 2). Taking into account the quantity of 

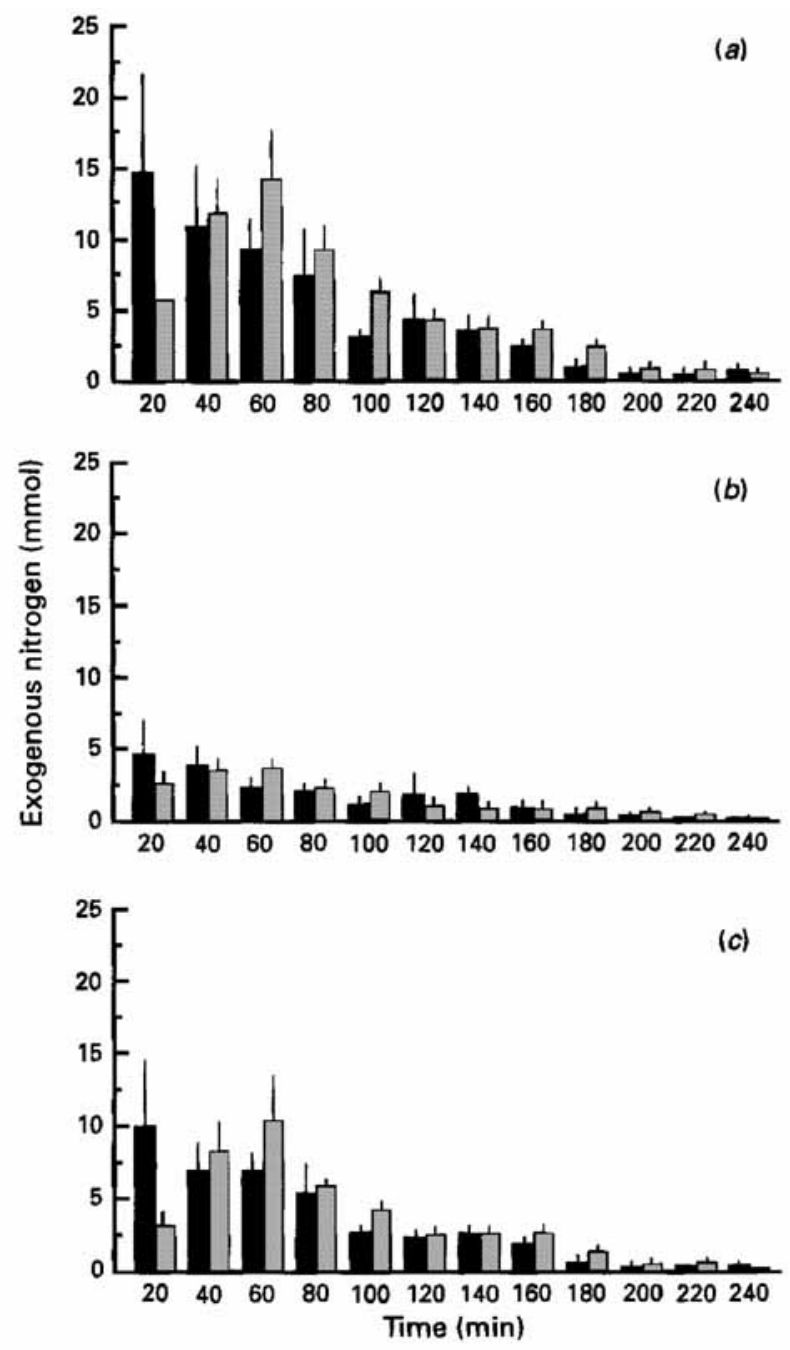

Fig. 3. Flow rates (mmol/20 $\mathrm{min}$ ) of $(a)$ total, $(b)$ protein and (c) non-protein exogenous nitrogen in the jejunum of humans ingesting either $300 \mathrm{ml}\left[{ }^{15} \mathrm{~N}\right]$ milk (⿴) or $300 \mathrm{~g}\left[{ }^{15} \mathrm{~N}\right]$ yoghurt (圈). The exogenous fraction was calculated from the ${ }^{15} \mathrm{~N}:{ }^{14} \mathrm{~N}$ ratio in the jejunal effluents. Values are means for seven (milk) or nine (yoghurt) subjects, with their standard errors indicated by vertical bars. For details of products and procedures, see Table 1 and pp. 252-253.

$\mathrm{N}$ ingested and the recovery of exogenous $\mathrm{N}$, the percentages of exogenous $\mathrm{N}$ absorbed at the jejunal level were 57 and $51 \%$ after milk and yoghurt ingestion respectively. No statistical differences were observed between the two groups of subjects, either for exogenous $\mathrm{N}$ absorption or for endogenous $\mathrm{N}$ secretion.

\section{DISCUSSION}

The ${ }^{15} \mathrm{~N}$ labelling of milk protein $\mathrm{N}$ allowed us to distinguish exogenous from endogenous $\mathrm{N}$ fractions in the human intestine after milk and yoghurt ingestion. In the present study this technique was used to demonstrate that (1) the gastro-duodenal transit of dietary $\mathrm{N}$ is 


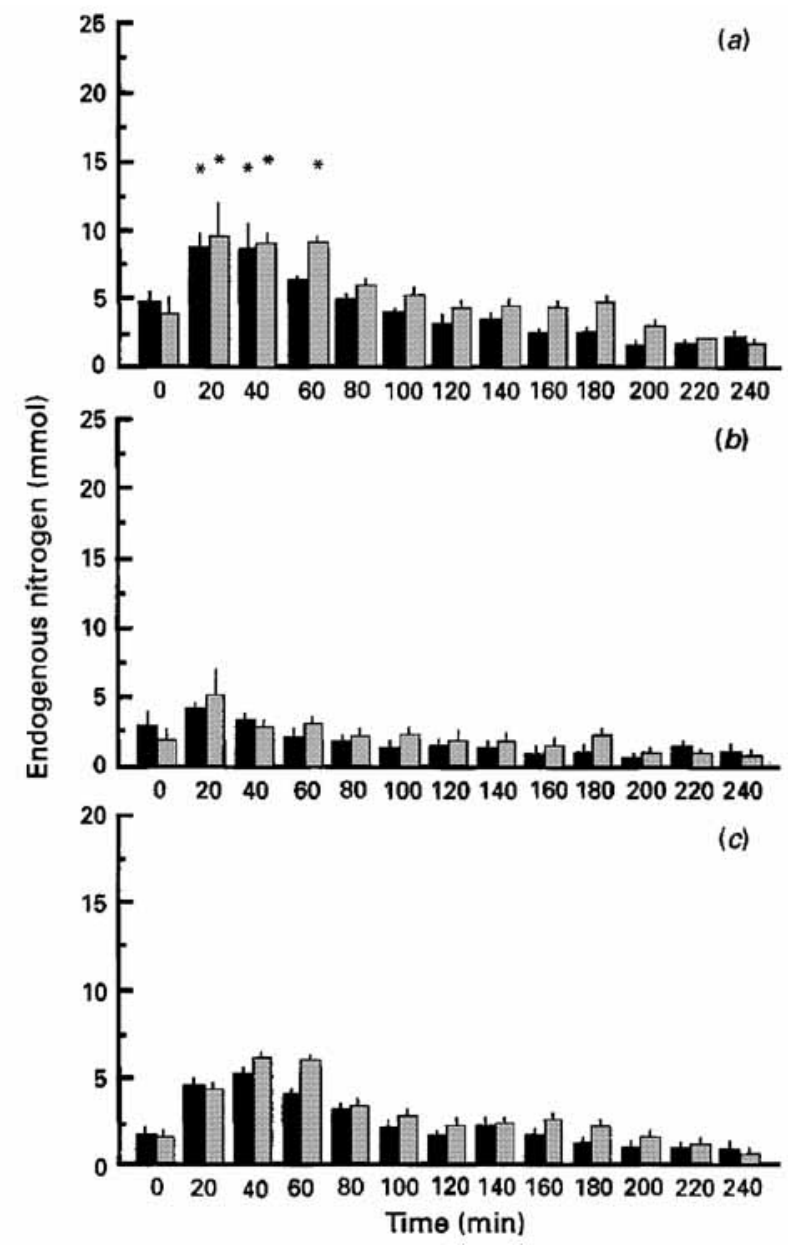

Fig. 4. Flow rates (mmol/20 min) of $(a)$ total, $(b)$ protein and $(c)$ non-protein endogenous nitrogen in the jejunum of humans ingesting either $300 \mathrm{ml}\left[{ }^{15} \mathrm{~N}\right] \mathrm{milk}(\square)$ or $300 \mathrm{~g}\left[{ }^{15} \mathrm{~N}\right]$ yoghurt (罞). The endogenous fraction was calculated as the difference between total nitrogen and the exogenous nitrogen fraction. Values are means for seven (milk) or nine (yoghurt) subjects, with their standard errors represented by vertical bars. ${ }^{*}$ Mean values were significantly different from the basal value $(P<0.05$, Tukey's studentized range test). For details of products and procedures, see Table 1 and pp. 252-253.

delayed with yoghurt in comparison with milk; (2) milk proteins are rapidly hydrolysed and absorbed in the proximal jejunum after both milk and yoghurt ingestion; (3) both milk and yoghurt significantly stimulate the endogenous $\mathrm{N}$ flow rate in the jejunum.

As previously observed (Gaudichon et al. 1994a; Mahe et al. 1994b), the N flow rate increased in the proximal jejunum after both milk and yoghurt ingestion but was delayed with yoghurt in comparison with milk. The difference could be due to differences in either the transit of the meal or the endogenous $\mathrm{N}$ response. The recovery of ${ }^{15} \mathrm{~N}$ in the intestinal lumen, which allowed us to calculate the exogenous $\mathbf{N}$ flow rate, clearly showed that the gastro-duodenal transit of the dietary $\mathrm{N}$ was delayed with yoghurt compared with milk due to a difference in the gastric emptying of the two diets. As previously described, this delay was due to a difference of food consistency and viscosity between milk and yoghurt (Houghton et al. 1987; Siegel et al. 1988; Mahé et al. 1994b). 
Table 2. Protein nitrogen $(P N)$ and non-protein nitrogen $(N P N)$ yields in the jejunal effluents of human subjects 240 min after milk $(M)$ and yoghurt $(Y)$ ingestion*

(Mean values with their standard errors)

\begin{tabular}{|c|c|c|c|c|c|c|c|c|c|c|c|c|}
\hline & \multirow{4}{*}{$\begin{array}{c}\text { Amount } \\
\text { ingested } \\
(\mathrm{mmol})\end{array}$} & \multirow[b]{4}{*}{$n$} & \multicolumn{8}{|c|}{ Amount recovered $(\mathrm{mmol}) \dagger$} & \multirow{3}{*}{\multicolumn{2}{|c|}{$\begin{array}{c}\text { Net } \\
\text { disappearance } \\
(\%)\end{array}$}} \\
\hline & & & \multicolumn{4}{|c|}{ Endogenous $\ddagger$} & \multicolumn{4}{|c|}{ Exogenous } & & \\
\hline & & & \multicolumn{2}{|c|}{ NPN } & \multicolumn{2}{|c|}{ PN } & \multicolumn{2}{|c|}{ NPN } & \multicolumn{2}{|c|}{$\mathrm{PN}$} & & \\
\hline & & & Mean & SEM & Mean & SEM & Mean & SEM & Mean & SEM & Mean & SEM \\
\hline $\mathbf{M}$ & 116 & 7 & $24 \cdot 6$ & 9.6 & $16 \cdot 6$ & 6.8 & 33.8 & 15.7 & 15.7 & 9.5 & 56.7 & 8.5 \\
\hline $\mathbf{Y}$ & 123 & 9 & 35.5 & $12 \cdot 0$ & $25 \cdot 1$ & $11 \cdot 8$ & 41.7 & 22.8 & 18.1 & $5 \cdot 2$ & 50.9 & 7.0 \\
\hline
\end{tabular}

* For details of products and procedures, see Table 1 and pp. 252-253.

$\uparrow$ No significant differences were found between the two groups $(P>0.05$, ANOVA).

$\ddagger$ Exogenous and endogenous $\mathrm{N}$ fractions were calculated from the ${ }^{15} \mathrm{~N}:{ }^{14} \mathrm{~N}$ ratio in jejunal effluents.

After milk and yoghurt ingestion the endogenous $\mathrm{N}$ flow rate increased significantly compared with the basal level. This increase could have been due to both a washing effect of the meal and a stimulation of gastric and bilio-pancreatic secretions. Such a stimulation was, however, not previously observed in subjects ingesting purified ${ }^{15} \mathrm{~N}$-labelled casein (Mahé et al. 1994c). This discrepancy probably arises from the differences in meal composition including higher energy intake and the presence of carbohydrates, lipids and a variety of proteins which can all influence pancreatic secretion (Corring et al. 1989). Both means tested in the present study had similar compositions and energy values and no difference of endogenous $\mathbf{N}$ stimulation after milk and yoghurt ingestion was observed. These observations suggest that the putative effect of casein-derived peptides on cholecystokinin production and intestinal secretions (Liddle et al. 1986) is not a major stimulant in humans, and that other factors present in the meal stimulate the endogenous $\mathrm{N}$ secretion. The present results also indicate that both milk and yoghurt proteins are rapidly degraded and absorbed in the human intestine. With both diets, exogenous NPN, i.e. hydrolysed fractions, represented $70-80 \%$ of the exogenous $\mathrm{N}$. This indicates that most of the milk and yoghurt proteins were in a hydrolysed form at the jejunal level. Similar values were reported in humans fed with purified casein (Mahé et al. 1994c). The secretion of proteases in the duodenum appears to be sufficient that the enzymic system is never saturated even when large amounts of dietary $\mathrm{N}$ are delivered into the intestine. The percentage exogenous $\mathrm{N}$ absorption in the jejunum was approximately $50 \%$ for both diets, indicating that a large fraction of the milk proteins was already absorbed in the duodenum. Another important aspect is the sensitivity of the endogenous $\mathrm{N}$ to digestion. The results showed that the endogenous PN $v$. NPN fractions remained stable, indicating a constant digestive secretion hydrolysis level.

The present results must be compared with those obtained from other studies in which the contribution of endogenous $\mathrm{N}$ was estimated in subjects ingesting a protein-free control diet (Mahé et al. 1992, 1994b), i.e. omitting the stimulation of endogenous $\mathrm{N}$ secretion by protein in the meal. This comparison shows that the error resulting from the use of this technique is not negligible. Several authors attempted to improve this technique by supplementing the protein free-diet with a casein hydrolysate that was supposedly completely digestible (Butts et al. 1993) or by giving a parenteral infusion of amino acids (DeLange et al. 1989) in order to stimulate the endogenous $\mathrm{N}$ secretion. Although these 
improvements are of interest, the first method could not be employed in a jejunal study because the absorption of the hydrolysate would not be achieved. Moreover, tracer methods are much more accurate in digestion studies since they allow the nitrogenous fractions to be followed directly. Due to ${ }^{15} \mathrm{~N}$ recycling and subsequent reappearance in the intestine, exogenous $\mathrm{N}$ absorption may be underestimated. However, in a $4 \mathrm{~h}$ study period the perturbation should be very slight, taking into account the time the amino acids need to appear in the plasma and to be incorporated into synthesized intestinal proteins. ${ }^{14} \mathrm{C}$ labelled amino acids have been shown not to reappear in the intestinal lumen of pigs via pancreatic secreta before 3-4 h after oral ingestion (Simon et al. 1983). In miniature pigs the overestimation of the total exogenous $\mathrm{N}$ from ${ }^{15} \mathrm{~N}$ dilution was less than $5 \%$ after $6 \mathrm{~h}$ when compared with reference values obtained with guanidinated casein (Hagemeister \& Roos, 1991). In humans we showed that $\left[{ }^{15} \mathrm{~N}\right]$ leucine, when infused directly into the plasma, appeared in digestive proteins after $2 \mathrm{~h}$ (Gaudichon et al. 1994b). In return, N can be recycled directly in the enterocyte without entering into the venous circulation. Little is known about this route of recycling and it would be of interest to quantify the consequent perturbation.

In conclusion, our results confirm that milk proteins are a good product for humans with regard to $\mathrm{N}$ intestinal availability. The ${ }^{15} \mathrm{~N}$-dilution technique is an appropriate method and helps to discriminate directly exogenous and endogenous $\mathbf{N}$ fractions in the human intestine after milk and yoghurt ingestion. We have demonstrated that both milk and yoghurt significantly stimulate the endogenous $\mathrm{N}$ flow rate in the jejunum and that a constant level of hydrolysis of digestive secretion is observed.

This work was supported in part by grant no. 1001/90 from the EEC. The authors wish to thank Miss M. Deyra for technical help and Suzanne Salter for her English assistance.

\section{REFERENCES}

Alpers, D. H. (1987). Digestion and absorption of carbohydrates and proteins. In Physiology of the Gastrointestinal Tract, pp. 1469-1487 [L. R. Johnson, editor]. New York: Raven Press.

Butts, C., Moughan, P. \& Wilson, M. (1993). Endogenous amino acid flow at the terminal ileum of adult humans determined following the ingestion of a single protein-free meal. Journal of the Science of Food and Agriculture 61, 439-442.

Corring, T., Juste, C. \& Lhoste, E. F. (1989). Nutritional regulation of pancreatic and biliary secretions. Nutrition Research Reviews 2, 161-180.

De Lange, C. F. M., Sauer, W. C., Mosenthin, R. \& Souffrant, W. B. (1989). The effect of feeding different protein-free diets on the recovery and amino acid composition of endogenous protein collected from the distal ileum and feces in pigs. Journal of Animal Science 67, 746-754.

Gaudichon, C., Laurent, C., Mahé, S., Marks, L., Tomé, D. \& Krempf, M. (1994a). Rate of $\left[{ }^{15}\right.$ N]leucine incorporation and determination of nitrogenous fractions from gastro-jejunal secretion in fasting humans. Reproduction Nutrition Development 34, 349-359.

Gaudichon, C., Roos, N., Mahé, S., Sick, H., Bouley, C. \& Tomé, D. (1994b). Gastric emptying is a major regulatory system of nitrogen absorption kinetics from $\left[{ }^{15} \mathrm{~N}\right]$-labelled milk and yoghurt in miniature pigs. Journal of Nutrition 124, 1970-1977.

Girard-Globa, A., Bourdel, G. \& Lardeux, B. (1980). Regulation of protein synthesis and enzyme accumulation in the rat pancreas by the amount and timing of dietary protein. Journal of Nutrition 110, 1380-1390.

Hagemeister, H. \& Roos, N. (1991). Comparison of protein digestibility measured by $\left[{ }^{15} \mathrm{~N}\right]$ and homoarginine. In Protein Metabolism and Nutrition. European Association for Animal Production Publication no. 59, pp. 36-38 [B. O. Eggum, S. Boisen, C. Borsting, A. Danfer and T. Hvelplund, editors]. Foulum, Denmark: National Institute of Animal Science.

Houghton, L. A., Hickson, F. \& Read, N. W. (1987). Effect of food consistency on gastric emptying in man. Gut 28, 1584-1588.

Liddle, R. A., Green, G. M., Conrad, C. K. \& Williams, J. A. (1986). Proteins but not amino acids, carbohydrate, or fats stimulate CCK secretion in the rat. American Journal of Physiology 251, G243-G248.

Lurie, B., Novis, B. H., Brom, B., Bank, S. \& Marks, I. N. (1973). Pancreatic exocrine responses to test meals of varying compositions in man. American Journal of Digestive Diseases 18, 847-850. 
Mahé, S., Huneau, J. F., Marteau, P., Thuillier, F. \& Tomé, D. (1992). Gastroileal nitrogen and electrolyte movements after bovine milk ingestion in humans. American Journal of Clinical Nutrition 56, 410-416.

Mahé, S., Fauquant, J., Gaudichon, C., Roos, N., Maubois, J. L. \& Tomé, D. (1994a). [ ${ }^{15}$ N]labelling and preparation of milk, casein and whey proteins. Lait 74, 307-312.

Mahé, S., Marteau, P., Huneau, J. F., Thuillier, F. \& Tomé, D. (1994b). Intestinal nitrogen and electrolyte movements following fermented milk ingestion in man. British Journal of Nutrition 71, 169-180.

Mahé, S., Roos, N., Benamouzig, R., Sick, H., Baglieri, A., Huneau, J. F. \& Tomé, D. (1994c). True exogenous and endogenous fractions in the human jejunum after ingestion of small amounts of ${ }^{15} \mathrm{~N}$-labeled casein. Journal of Nutrition 124, 548-555.

Siegel, J. A., Urbain, J. L., Adler, L. P., Charkes, N. D., Maurer, A. H., Krevsky, B., Knight, L. C., Fisher, R. S. \& Malmud, L. S. (1988). Biphasic nature of gastric emptying. Gut 29, 85-89.

Simon, O., Zebrowska, T., Bergner, H. \& Münchmeyer, R. (1983). Investigations on the pancreatic and stomach secretion in pigs by the means of continuous infustion of ${ }^{14} \mathrm{C}$-amino acids. Archiv für Tierernährung 33, 9-22. 